\title{
Effects of Modified Atmosphere Packaging (MAP) and slaughter age on the shelf life of lamb meat
}

\author{
Evelyn von Rosen STAHLKE ${ }^{1}$, Luciane Silvia ROSSA ${ }^{1}$, Giovana Maria SILVA ${ }^{1}$, Cristina Santos SOTOMAIOR ${ }^{1}$, \\ Antônio Juglair PEREIRA ${ }^{1}$, Fernando Bittencourt LUCIANO ${ }^{1}$, Tâmara Duarte BORGES ${ }^{1}$, \\ Renata Ernlund Freitas de MACEDO $^{1 \star}$
}

\begin{abstract}
The shelf life extending effect of different modified atmospheres packages (MAP): vacuum (MAP-1), $69.6 \% \mathrm{~N}_{2}+30 \% \mathrm{CO}_{2}+0.4 \% \mathrm{CO}$ (MAP-2) and $70 \% \mathrm{O}_{2}+30 \% \mathrm{CO}_{2}$ (MAP-3) on lamb meat at two slaughter ages (4 and 8-month-old) was assessed. pH decreased as slaughter age (SA) increased, and increased during longer storage time (ST), with no MAP effects. Lamb meat stored in MAP-1 and MAP-3 showed greater drip loss than that stored in MAP-2. Shear force was not influenced by SA and MAP treatments, but decreased during ST. Meat from 8-month-old lambs packaged in MAP-3 at longer ST resulted in lipid oxidation increase. MAP-2 enhanced color saturation and lamb meat redness, whereas MAP-3 showed lowest redness and chroma values, and highest aerobic psychrotropic count. Meat from 4-month-old lamb stored in MAP-3 presented shortest shelf life based on psychrotropic bacteria growth. The association of higher SA with high $\mathrm{O}_{2}$ MAP proved to compromise oxidative stability of lamb meat, adversely affecting its shelf life. Vacuum and CO packaging showed similar effects on lamb meat preservation; however, $\mathrm{CO}$ had advantage in maintaining fresh red color of meat.
\end{abstract}

Keywords: lamb; lipid oxidation; microbial growth; storage.

Practical Application: High $\mathrm{O}_{2}$ packaging affects lipid oxidation, bacteria growth and lamb meat redness over storage.

\section{Introduction}

In the last years, production and demand for lamb meat has greatly increased in Brazil (Fernandes et al., 2010), mostly in the southern states of the country. However, due to the reproductive seasonality of sheep, lamb meat supply is concentrated in November-March (end of spring and summer in Brazil), with product shortages during the winter and decrease during spring seasons. Therefore, lamb meat is generally marketed in frozen form in Brazil. In this form it lasts 12 months, with physical chemical, microbial and sensory quality parameters well preserved. Although freezing has proven to be effective in preventing microbial spoilage, it does not meet the current consumer demand for convenience and freshness (Lauzurica et al., 2005).

Vacuum packaging is traditionally used to preserve chilled meat, however, vacuum makes red meats darkened, lowering their attractiveness (Renerre, 1990). In order to minimize this effect, the modification of gas composition within food package may constitute an interesting method (Zakrys et al., 2009). Thus, Modified Atmosphere Packaging (MAP) could preserve chilled lamb's meat keeping its attractiveness, extend its shelf life, and stimulate the consumption.

Due to its chemical characteristics such as higher $\mathrm{pH}$, chilled lamb meat is more susceptible to chemical and microbiological deterioration when compared to beef, which has been effectively preserved only by using vacuum packaging. Thus, the development of different effective packaging methods to preserve chilled lamb's meat is required (Kennedy et al., 2004).

Modified atmosphere in combination with low temperature storage has long been considered an important technology to preserve the quality standards and to extend the shelf life in fresh meat (Parry, 1993; Baracat et al., 2005). In addition to delaying the growth of spoilage microorganisms in meat, modified atmosphere also contributes to the reduction of lipid oxidation, which may result in a rancid odor and taste.

In highly perishable foods, such as fresh meat, a proper combination of gases must be applied to reach a longer shelf life. Among the most used gases in fresh meat packages, $\mathrm{CO}_{2}$ is partially soluble in water and fat and has antimicrobial activity. The $\mathrm{O}_{2}$ gas can help to preserve the desirable bright red color (oxymyoglobin) of meat; however $\mathrm{O}_{2}$ can promote lipid and myoglobin oxidation rather quickly, resulting in discoloration, i.e., the formation of metmyoglobin (Jakobsen \& Bertelsen, 2000; Mancini et al., 2005; Bórnez et al., 2010).

More recently, the use of carbon monoxide (CO) in combination with other gases has been proposed in fresh red meat packages (Huffman \& Rilley, 2007) In low concentration (less than 1\%) in the gas mixture, $\mathrm{CO}$ can increase the oxidative stability and color in lamb meat (Linares et al., 2007), pork 
(Wilkinson et al., 2006), beef (Jayasingh et al., 2001) or turkey (Pexara et al., 2002). In addition, the use of this gas at levels $<1 \%$ is completely safe for consumers (Sørheim et al., 2009) and has been allowed in countries such as the United States, New Zealand and Australia since 2004.

The effect of different gases in modified atmosphere has been studied in lamb meat (Lauzurica et al., 2005; Vergara \& Gallego, 2001; Kennedy et al., 2004; Linares et al., 2008), however, there is a lack of studies on the influence of the animal age on the preservation effect of MAP package in lamb meat (Linares et al., 2007).

Traditionally, the Brazilian lamb meat market is supplied by animals slaughtered at 3-5 months; nevertheless, many farmers are increasing the live weight at slaughter and, consequently, the slaughter age of animals. Considering the continuous request for high quality lamb meat in Brazil and the impact of the slaughter age on lamb meat quality, the aim of this study was to evaluate the effect of different Modified Atmosphere Packaging (MAP) and Slaughter Ages (SA) on the shelf life of lamb meat.

\section{Materials and methods}

\subsection{Packaging methods, materials and storage}

Twenty eight (28) male, non-castrated, crossbred Texel and Ile de France lambs at two different slaughter ages, 4 and 8 months, were randomly selected and assigned for this study. Animals were raised in a farm in the city of Castro, State of Paraná, Brazil (situated at latitude $24^{\circ} 47^{\prime} 32^{\prime \prime}$ south, longitude $50^{\circ} 0^{\prime} 42^{\prime \prime}$ west and altitude $996 \mathrm{~m}$ above sea level), finished under feedlot conditions and fed with corn silage, commercial concentrate, and mineral salt. Animal handling procedures were approved by the Ethics Committee on Animal Use (CEUA) of PUCPR under protocol number 552.

As animals reached average live weight of 38 and $45 \mathrm{~kg}$ for 4 and 8-month-old, respectively, they were transported from farm to the slaughterhouse $(10 \mathrm{~km})$ under Federal Inspection Service (SIF), from the Brazilian Ministry of Agriculture, Livestock and Food Supply (MAPA), following the guidelines of Department of Animal Products Inspection (DIPOA), and also under inspection on humane slaughter regulation by the Normative Instruction number 3 (Brasil, 2000).

Carcasses were chilled for $24 \mathrm{~h}$ at $4{ }^{\circ} \mathrm{C}$ and the longissimus thoracis et lumborum (LTL) from both sides of the carcasses was removed. Muscles were trimmed of external fat and cut into similar size portions ( $140 \mathrm{~g})$. Portions were randomly distributed into 6 treatments (two slaughter ages $\mathrm{x}$ three modified atmospheres):

$$
\begin{aligned}
& -4 \text { months + MAP } 1 \text { (vacuum packaging); } \\
& -4 \text { months + MAP } 2\left(69.6 \% \mathrm{~N}_{2}+30 \% \mathrm{CO}_{2}+0.4 \% \mathrm{CO}\right) ; \\
& -4 \text { months + MAP } 3\left(70 \% \mathrm{O}_{2}+30 \% \mathrm{CO}_{2}\right) ; \\
& -8 \text { months + MAP } 1 \text { (vacuum packaging); } \\
& -8 \text { months + MAP } 2\left(69.6 \% \mathrm{~N}_{2}+30 \% \mathrm{CO}_{2}+0.4 \% \mathrm{CO}\right) ; \\
& -8 \text { months + MAP } 3\left(70 \% \mathrm{O}_{2}+30 \% \mathrm{CO}_{2}\right) .
\end{aligned}
$$

Samples were packed under modified atmosphere in ethylene vinyl alcohol (EVOH) packaging with a permeability of $4 \mathrm{~cm}^{3} \mathrm{O}_{2} / \mathrm{m}^{2}$ per day at $1 \mathrm{ATM}$ and $23^{\circ} \mathrm{C}$ (RMB Máquinas e Embalagens, Curitiba, Paraná, Brazil) and packaged using a packaging machine (Selovac 200B, São Paulo, Brazil). The gas mixtures used in packages were defined according to Bórnez et al. (2010). Samples were placed in a refrigeration chamber (Fanem, $347 \mathrm{CD}$, São Paulo, Brazil) at $4{ }^{\circ} \mathrm{C}$ in dark conditions and stored for 35 days.

\subsection{Analyses}

$p H$

The $\mathrm{pH}_{24 \mathrm{~h}}$ was performed using a digital $\mathrm{pHmeter}$ (Quimis, São Paulo, Brazil) with a penetrating electrode.

\section{Drip Loss (DL)}

DL was measured by gravimetric method on an analytical weighing scale (Gehaka, AG 200, São Paulo, Brazil) and expressed as a percentage of the initial portion weight (Association of Official Analytical Chemists, 2000).

\section{Shear Force (SF)}

SF was determined in samples cooked as previously described and cut in $1.27 \mathrm{~cm}$ cylindrical shape. Samples were sheared in a texturometer TAXT2i (Stable Micro Systems, Surrey, England) equipped with a Warner-Bratzler blade (Kerth et al., 1995; American Meat Science Association, 1995) SF was taken perpendicularly to the direction of muscle fibers, with $1.5 \mathrm{~mm} / \mathrm{s}$ test speed and $30 \mathrm{~mm}$ distance from the base (Linares et al., 2006).

\section{Lipid oxidation (TBARS)}

TBARS were determined according to the method described by Vyncke (1970) and absorbance reading was conducted in a spectrophotometer (Milton Roy, Spectronic 21D, Waltham, USA) at $538 \mathrm{~nm}$ and the result expressed as $\mathrm{mg}$ of malonaldehyde (MDA) per kg of sample.

\section{Instrumental color}

The instrumental color of samples was assessed using the method of American Society for Testing and Material (2001) with a colorimeter (Konica Minolta CR 410, Osaka, Japan) and the CIE color coordinates $\mathrm{L}^{*}, \mathrm{a}^{*}, \mathrm{~b}^{*}$. The measurement was conducted through the average of 5 shots directly on the surface of samples using illuminant $\mathrm{C}$, opening diameter from 50 to $53 \mathrm{~mm}$, and an observation angle of $2^{\circ}$. $C^{*}$ (chroma) $\left(c=\sqrt{ } \mathrm{a}^{2} \mathrm{x} \mathrm{b}^{2}\right)$ and hue $(\mathrm{h}=$ ARCTAN $(\mathrm{b} / \mathrm{a}))$ values were calculated from the results of $\mathrm{a}^{*}$ and $\mathrm{b}^{*}$.

\section{Microbiological determinations}

The total aerobic psychrotrophic bacteria was determinate by plating on Plate Count Agar (PCA) (HIMEDIA, M091, Mumbai, India) with incubation at $17^{\circ} \mathrm{C}$ for 16 hours, followed by another incubation at $4{ }^{\circ} \mathrm{C}$ for 72 hours. The total coliform 
and Escherichia coli count were performed on Petrifilm ${ }^{\mathrm{TM}}$ plates (3M, St. Paul, USA), with incubation at $37^{\circ} \mathrm{C}$ for 48 hours and lactic acid bacteria count was performed on MRS agar (de Man, Rogosa, and Sharpe - HIMEDIA, M1163, Mumbai, India), with incubation at $37^{\circ} \mathrm{C}$ for 48 hours. All determinations were performed in duplicate and according to methodologies recommended for fresh meat by the Brazilian legislation (Brasil, 2003; Silva et al., 2010). The results were expressed as log CFU/g of sample.

\section{Storage Time (ST)}

All samples were assessed for physical chemical and microbiological parameters at different intervals as described below:

- Storage time 0, 7, 14, 21, 28 and 35-days (five samples of each treatment for each sampling day): $\mathrm{pH}$, drip loss, shear force, lipid oxidation, instrumental color, count of aerobic psychrotrophic bacteria, lactic acid bacteria, total coliform and Escherichia coli.

The experiment was conducted twice. Therefore, 180 meat portions were used for each experiment, totalizing 360 portions for the overall study.

\subsection{Statistics}

The experimental design was completely randomized in a factorial scheme $2 \times 3 \times 6$, with 2 slaughter ages, 3 atmospheres and 6 times. Slaughter age (SA), atmosphere (MAP) and Storage time (ST) were analyzed as fixed effects using the General Linear Model with the software Statgraphics Centurion XVI, version 16.1.11, as well as their interaction according to the following mathematical model (Equation 1):

$Y_{i j k}=\mu+I_{i}+A_{j}+T_{m}+I_{i} * A_{j} T_{m}+e_{i j m k}$

where: $\mathrm{Y}_{\text {ijmk }}=$ value; $\mu=$ mean; $\mathrm{I}_{\mathrm{i}}=$ effect of $\mathrm{SA}(\mathrm{i}=1,2) ; \mathrm{A}_{\mathrm{i}}=$ effect of $\operatorname{MAP}(j=1,2,3) ; \mathrm{T}_{\mathrm{m}}=$ effect of ST $(\mathrm{m}=1,2,3,4,5,6) ; \mathrm{I}_{\mathrm{i}}{ }^{*} \mathrm{~A}_{\mathrm{j}}{ }^{*} \mathrm{~T}_{\mathrm{m}}=$ effect of the interaction between SA x MAP x ST; $\mathrm{e}_{\mathrm{ijmk}}=$ random error.
In cases where the interaction among SA, MAP and ST was not significant $(P>0.05)$, interaction was removed from the model and the main effects of SA, MAP and ST were analyzed. The averages obtained for SA, MAP, ST or the SA x MAP x ST interaction were compared by means of Tukey's test, using a $5 \%$ significance level.

Microbiological shelf life was estimated with regard to the count of psychrotrophic bacteria and lactic acid bacteria through nonlinear regression calculated by means of the Marquardt procedure, using the least-squares method with the software Table Curve 2D, version 5.01.02.

\section{Results and discussion}

The interaction between MAP X SA X ST was significant $(\mathrm{P} \leq 0.05)$ for $\mathrm{pH}, \mathrm{a}^{\star}, \mathrm{C}^{*}, \mathrm{~b}^{\star}$, lipid oxidation, acid lactic bacteria, total coliforms and psychrotrophic bacteria.

\section{$3.1 p H$}

At all MAPs, $\mathrm{pH}$ decreased with increasing slaughter age and increased with longer storage time $(\mathrm{P}<0.05)$. Samples from 4-month-old animals showed higher $\mathrm{pH}$ values when compared to those from 8-month-old (Table 1).

Regarding the effect of SA on $\mathrm{pH}$ lamb meat, authors reported that final $\mathrm{pH}$ of lamb meat tends to exhibit lower values with increased animal age (Devine et al., 1993; McGeehin et al., 2001). Kim et al. (2012a) also observed a slightly increased $\mathrm{pH}$ during storage in meat from lambs slaughtered at 3 and 10 months with increased average value from 5.68 to 5.81 over 8 weeks in vacuum storage under refrigeration.

MAP showed no individual effect on $\mathrm{pH}$ (Table 1). Some authors reported that $\mathrm{CO}_{2}$ decreases meat $\mathrm{pH}$, once it solubilized in water transforming itself in carbonic acid (Martínez-Cerezo et al., 2005; Karabagias et al., 2011). However, among the different MAP used in our study, no effect in lamb meat $\mathrm{pH}(\mathrm{P}>0.05)$ was found. Linares et al. (2008) and Bórnez et al. (2010) studying lamb meat of Manchega breed in Spain did also not

Table 1. Effect of Slaughter Age (SA) and Modified Atmosphere Packaging (MAP) on the pH, Drip loss (DL), Shear force (SF), Lipid Oxidation (TBARS) and instrumental color of chilled lamb meat after 35-days of storage (Mean \pm Standard Error).

\begin{tabular}{|c|c|c|c|c|c|}
\hline \multirow{3}{*}{ Color } & \multicolumn{5}{|c|}{ Treatment } \\
\hline & \multicolumn{2}{|c|}{ Slaughter age } & \multicolumn{3}{|c|}{ Atmosphere $^{1}$} \\
\hline & 4 months & 8 months & MAP 1 & MAP 2 & MAP 3 \\
\hline $\mathrm{pH}$ & $5.77^{\mathrm{a}} \pm 0.01$ & $5.73^{b} \pm 0.01$ & $5.76^{\mathrm{a}} \pm 0.01$ & $5.73^{a} \pm 0.01$ & $5.76^{a} \pm 0.01$ \\
\hline DL (\%) & $4.86^{a} \pm 0.26$ & $4.70^{\mathrm{a}} \pm 0.26$ & $5.22^{\mathrm{b}} \pm 0.32$ & $3.98^{\mathrm{a}} \pm 0.32$ & $5.15^{\mathrm{b}} \pm 0.32$ \\
\hline SF (kg) & $2.72^{\mathrm{a}} \pm 0.05$ & $2.61^{\mathrm{a}} \pm 0.05$ & $2.56^{\mathrm{a}} \pm 0.06$ & $2.75^{\mathrm{a}} \pm 0.06$ & $2.68^{a} \pm 0.06$ \\
\hline TBARS & $1.35^{\mathrm{a}} \pm 0.20$ & $2.78^{b} \pm 0.20$ & $0.44^{\mathrm{a}} \pm 0.24$ & $0.54^{\mathrm{a}} \pm 0.24$ & $5.22^{\mathrm{b}} \pm 0.24$ \\
\hline $\mathrm{L}^{*}$ & $47.02^{\mathrm{a}} \pm 0.29$ & $47.19^{\mathrm{a}} \pm 0.29$ & $46.73^{\mathrm{a}} \pm 0.36$ & $47.51^{\mathrm{a}} \pm 0.36$ & $47.02^{\mathrm{a}} \pm 0.36$ \\
\hline$a^{*}$ & $21.84^{\mathrm{b}} \pm 0.17$ & $20.93^{\mathrm{a}} \pm 0.17$ & $20.89^{b} \pm 0.21$ & $23.27^{\mathrm{c}} \pm 0.21$ & $20.00^{\mathrm{a}} \pm 0.21$ \\
\hline$b^{*}$ & $6.89^{a} \pm 0.12$ & $7.23^{\mathrm{a}} \pm 0.12$ & $6.77^{\mathrm{a}} \pm 0.15$ & $7.39^{b} \pm 0.15$ & $7.03^{\mathrm{ab}} \pm 0.15$ \\
\hline Hue & $17.69^{\mathrm{a}} \pm 0.34$ & $19.33^{\mathrm{b}} \pm 0.34$ & $18.13^{\mathrm{a}} \pm 0.42$ & $17.81^{\mathrm{a}} \pm 0.42$ & $19.60^{\mathrm{b}} \pm 0.42$ \\
\hline $\mathrm{C}^{*}$ & $22.97^{b} \pm 0.17$ & $22.24^{\mathrm{a}} \pm 0.17$ & $22.05^{\mathrm{b}} \pm 0.21$ & $24.49^{c} \pm 0.21$ & $21.28^{\mathrm{a}} \pm 0.21$ \\
\hline
\end{tabular}

Different lower-case letters at the same row for the same SA or MAP indicate a significant $(\mathrm{P} \leq 0.05)$ difference; ${ }^{1} \mathrm{MAP} 1=$ vacuum packaging; $\mathrm{MAP} 2=69.6 \% \mathrm{~N}_{2}+30 \% \mathrm{CO}+0.4 \% \mathrm{CO}$; MAP $3=70 \% \mathrm{O}_{2}+30 \% \mathrm{CO}_{2}$. 
observe differences in $\mathrm{pH}$ of meat stored under $\mathrm{O}_{2}, \mathrm{CO}_{2}$ or $\mathrm{CO}\left(69.3 \% \mathrm{~N}_{2}+30 \% \mathrm{CO}_{2}+0.7 \% \mathrm{CO} ; 70 \% \mathrm{O}_{2}+30 \% \mathrm{CO}_{2}\right)$ atmosphere packing. Linares \& Vergara (2012) did also find no effect of high $\mathrm{O}_{2}$ $\left(70 \% \mathrm{O}_{2}+30 \% \mathrm{CO}_{2}\right)$ and $\mathrm{CO}\left(69.3 \% \mathrm{~N}_{2}+30 \% \mathrm{CO}_{2}+0.7 \% \mathrm{CO}\right)$ atmospheres on the $\mathrm{pH}$ of meat from lamb slaughtered at 70-days of age.

After 35-day of storage, meat $\mathrm{pH}$ values from all treatments varied from 5.70 (MAP 1 and 2) to 6.06 (MAP 3) and remained below 6.2, considered as the limit for fresh red meat consumption (Brasil, 1981). Samples from all treatments showed a slight increase in $\mathrm{pH}$ over the storage time (Table 2) due to normal autolysis process and ageing (Martínez-Cerezo et al., 2005).

\subsection{DL}

MAP and ST showed effect on the $\mathrm{DL}(\mathrm{P} \leq 0.05)$. Lamb meat stored under vacuum (MAP 1) and high $\mathrm{O}_{2}$ concentration (MAP 3) showed greater DL than lamb stored in CO (MAP 2) (Table 1). DL values also increased over time, varying from $3.27 \% \pm 0.42$ to $6.14 \% \pm 0.42$ at 7 and 35 days of storage, respectively (Table 2).

Vacuum packaged meat tends to exhibit higher DL due to the pressure exerted by the packaging on the product, which is one of the major disadvantages in the use of this method (Seman et al., 1989). Similar effect of high-oxygen packages on the increase of DL was also found in pork (Lund et al., 2007) and beef (Seyfert et al., 2005), due to the myosin oxidation and cross-linking reactions, which are favored in the presence of oxygen in the packing atmosphere.

Also DL increase was related to storage time. The phenomenon of increasing drip loss on lamb muscle results from a graduate loss in ability of lamb proteins to retain water as the storage time progresses (Church \& Parsons, 1995).

DL values in lamb meat in the present study were higher than those found by Kim et al. (2012a) for chilled lamb meat from animals slaughtered at 4 and 11 months (1.6\% and $1.5 \%$, respectively), and stored under vacuum for 8 weeks. Linares \& Vergara (2012) also reported lower DL values in meat from lambs slaughtered at 70 -days, whose values ranged from $2.2 \%$ to $3.1 \%$ after 21 days of storage under refrigeration in MAP. These differences in DL might be related to the different techniques used by authors to determine this parameter (Linares et al., 2006).

\subsection{SF}

No significant variations were detected in SF among different MAP or SA treatments $(\mathrm{P}>0.05)$ after 35 days of storage. However, SF was affected by ST $(\mathrm{P} \leq 0.05)$ (Table 2). SF values decreased during storage time, which may be attributed to the extensive action of proteolytic enzymes on meat myofibrils during long storage time (Kim et al., 2012a).

In general, meat tenderness decreases as an animal gets older most likely due to an increase in collagen content and extent of collagen cross-linking (Prandl et al., 1994). However, in the present study, those differences were not detected. These results were likely due to a relatively small difference in animal's age (4-month apart), which may be not enough to differing collagen content between these two age categories. Kim et al. (2012a) also found no significant effect of slaughter age on SF of meat from lambs slaughtered at 3 and 10 months, kept in vacuum storage under refrigeration for 8 weeks.

Similarly to the present study, Fernandes et al. (2014) and Linares et al. (2006) found no effect of different MAP (vacuum; 75\% $\mathrm{O}_{2}+25 \% \mathrm{CO}_{2} ; 100 \% \mathrm{CO}_{2} ; 70 \% \mathrm{O}_{2}+30 \% \mathrm{CO}_{2}$; $69.3 \% \mathrm{~N}_{2}+30 \% \mathrm{CO}_{2}+0.7 \% \mathrm{CO} ; 40 \% \mathrm{CO}_{2}+60 \% \mathrm{~N}_{2}$ ) on $\mathrm{SF}$ of lamb stored under refrigeration. In contrast, Bórnez et al. (2009) assessed lamb longissimus dorsi muscles after 7, 14 and 21 days of storage at $2{ }^{\circ} \mathrm{C}$ in two types of atmospheres $\left(70 \% \mathrm{O}_{2}+30 \% \mathrm{CO}_{2}\right.$ and $69.3 \% \mathrm{~N}_{2}+30 \% \mathrm{CO}_{2}+0.7 \% \mathrm{CO}$ ) reported that the high $\mathrm{O}_{2}$ atmosphere resulted in a significant decrease in $\mathrm{SF}$ throughout the evaluated storage period.

\subsection{TBARS}

SA, MAP and ST showed an interaction effect on lipid oxidation of lamb meat $(\mathrm{P} \leq 0.05)$. The loins from older animals, packaged in high oxygen atmosphere and at longer storage time resulted in an increase $(\mathrm{P} \leq 0.05)$ in TBARS values (Table 1$)$.

Xiong et al. (2007) found a decrease in the oxidative stability of meat with advance in animal's age. The higher lipid oxidation in meat from older animals may also be related to the higher slaughter weight of these animals, which influences on the composition of intramuscular fat of lamb meat that becomes more unsaturated as the animal slaughter weight increases (Linares et al., 2007).

Table 2. Effect of storage time (ST) on pH, Drip loss (DL), Shear force (SF), lipid oxidation (TBARS), instrumental color L* (lightness), $\mathrm{a}^{\star}$ (redness) $\mathrm{b}^{*}$ (yellowness), $\mathrm{C}^{\star}$ (chroma), total coliform (TC), latic acid bacteria (LAB) and psychrotrophic bacteria (PB) of chilled lamb meat after 35-days of storage (Mean \pm Standard Error).

\begin{tabular}{cccccccccccccccc}
\hline $\mathrm{ST}$ & $\mathrm{pH}$ & $\mathrm{DL}$ & $\mathrm{SF}$ & $\mathrm{TBARS}$ & $\mathrm{L}^{*}$ & $\mathrm{a}^{*}$ & $\mathrm{~b}^{*}$ & $\mathrm{C}^{*}$ & $\mathrm{TC}$ & $\mathrm{LAB}$ & $\mathrm{PB}$ & \\
\hline 0 & $5.52^{\mathrm{a}} \pm 0.02$ &. & $3.58^{\mathrm{c}} \pm 0.09$ &. & $51.26^{\mathrm{c}} \pm 0.51$ & $16.88^{\mathrm{a}} \pm 0.29$ & $7.01^{\mathrm{abc}} \pm 0.21$ & $18.45^{\mathrm{a}} \pm 0.30$ & $1.00^{\mathrm{a}} \pm 0.15$ & $3.55^{\mathrm{a}} \pm 0.10$ & $4.90^{\mathrm{ab}} \pm 0.10$ \\
7 & $5.83^{\mathrm{b}} \pm 0.02$ & $3.27^{\mathrm{a}} \pm 0.42$ & $2.77^{\mathrm{b}} \pm 0.09$ &. & $44.51^{\mathrm{a}} \pm 0.51$ & $22.06^{\mathrm{bc}} \pm 0.29$ & $6.45^{\mathrm{a}} \pm 0.21$ & $23.03^{\mathrm{bc}} \pm 0.30$ & $1.33^{\mathrm{a}} \pm 0.15$ & $4.52^{\mathrm{b}} \pm 0.10$ & $5.33^{\mathrm{b}} \pm 0.10$ \\
14 & $5.92^{\mathrm{b}} \pm 0.02$ & $4.56^{\mathrm{abc}} \pm 0.42$ & $2.48^{\mathrm{ab}} \pm 0.09$ & $1.51^{\mathrm{a}} \pm 0.28$ & $44.48^{\mathrm{a}} \pm 0.51$ & $22.68^{\mathrm{bc}} \pm 0.29$ & $6.77^{\mathrm{ab}} \pm 0.21$ & $23.70^{\mathrm{bc}} \pm 0.30$ & $2.34^{\mathrm{b}} \pm 0.15$ & $6.67^{\mathrm{c}} \pm 0.10$ & $7.85^{\mathrm{c}} \pm 0.10$ \\
21 & $5.92^{\mathrm{b}} \pm 0.02$ & $4.38^{\mathrm{ab}} \pm 0.42$ & $2.37^{\mathrm{a}} \pm 0.09$ & $2.05^{\mathrm{ab}} \pm 0.28$ & $47.29^{\mathrm{b}} \pm 0.51$ & $22.74^{\mathrm{c}} \pm 0.29$ & $7.43^{\mathrm{bc}} \pm 0.21$ & $23.96^{\mathrm{c}} \pm 0.30$ & $3.35^{\mathrm{c}} \pm 0.15$ & $7.59^{\mathrm{d}} \pm 0.10$ & $8.19^{\mathrm{c}} \pm 0.10$ \\
28 & $5.50^{\mathrm{a}} \pm 0.025$ & $5.56^{\mathrm{bc}} \pm 0.42$ & $2.43^{\mathrm{ab}} \pm 0.09$ & $2.04^{\mathrm{ab}} \pm 0.28$ & $46.99^{\mathrm{b}} \pm 0.51$ & $22.46^{\mathrm{bc}} \pm 0.29$ & $7.68^{\mathrm{c}} \pm 0.21$ & $23.82^{\mathrm{bc}} \pm 0.30$ & $1.52^{\mathrm{a}} \pm 0.15$ & $7.40^{\mathrm{cd}} \pm 0.10$ & $8.28^{\mathrm{c}} \pm 0.10$ \\
35 & $5.82^{\mathrm{b}} \pm 0.025$ & $6.14^{\mathrm{c}} \pm 0.42$ & $2.36^{\mathrm{a}} \pm 0.09$ & $2.66^{\mathrm{b}} \pm 0.28$ & $48.10^{\mathrm{b}} \pm 0.51$ & $21.51^{\mathrm{b}} \pm 0.29$ & $7.04^{\mathrm{abc}} \pm 0.21$ & $22.68^{\mathrm{b}} \pm 0.30$ & $1.00^{\mathrm{a}} \pm 0.15$ & $7.89^{\mathrm{d}} \pm 0.10$ & $8.32^{\mathrm{c}} \pm 0.10$ \\
\hline
\end{tabular}

Different lower-case letters at the same column indicate a significant $(\mathrm{P} \leq 0.05)$ difference. 
The significant effect of storage time and high oxygen atmosphere (MAP 3) on lipid oxidation is consistent with previous studies (Zakrys et al., 2008; Kim et al., 2011, 2012b) where high oxygen atmospheres induced greater extent of lipid oxidation of fresh meat during storage compared to lower oxygen or anaerobic packaging conditions. An increase in lipid oxidation is associated with rancid odor or undesirable flavor of meat product (Zakrys et al., 2008).

Linares et al. (2007) observed that a high concentration of oxygen in the atmosphere (70\%) favored lipid oxidation and that the addition of low CO concentration $(0.7 \%)$ led to lower oxidation of lamb meat by forming a stable pigment, the carboxymyoglobin. Higher myoglobin color stability is related to the lower lipid oxidation in lamb meat (Guidera et al., 1997; Kennedy et al., 2004).

In the present study, samples packaged under addition of $\mathrm{CO}$ (MAP 2) and under vacuum (MAP 1) had TBARS content lower than that of samples packaged under a high $\mathrm{O}_{2}$ concentration (70\%) (MAP 3) (Table 1). Linares \& Vergara (2012) observed the lipid oxidation level in lamb loin stored for 21 days under an atmosphere rich in $\mathrm{O}_{2}(70 \%) 3$ times higher than the oxidation observed in loin stored under the same conditions in an atmosphere containing CO (0.7\%). Kim et al. (2012b) also observed a significant interaction between an atmosphere with high oxygen content and SA on the lipid oxidation of lamb meat. The authors identified that lipid oxidation in lamb loin stored under an atmosphere rich in $\mathrm{O}_{2}$ was higher for animals slaughtered at 10 months when compared to those slaughtered at 3 months.

According to Watts (1962) and Camo et al. (2008), the TBARS concentration of $2.0 \mathrm{mg} / \mathrm{kg}$ is considered as the limit to the sensory acceptance of lamb meat. However, the concentration of malondialdehyde in meat must be higher than $5 \mathrm{mg} / \mathrm{kg}$ to be perceptible to the human olfactory (Insausti et al., 2001). Considering the value of $2 \mathrm{mg} / \mathrm{kg}$ as the maximum threshold for the concentration of malondialdehyde in meat, loin packaged in MAP 1 and MAP 2 at both slaughter ages showed mean TBARS values $\leq 0.5 \mathrm{mg}$ malondialdehyde $/ \mathrm{kg}$. In turn, samples packaged in high $\mathrm{O}_{2}$ concentration (MAP 3) reached a value over $2 \mathrm{mg}$ malonaldehyde/ $\mathrm{kg}$ after 14 days of storage (mean values of 3.15 and $7.28 \mathrm{mg}$ malondialdehyde $/ \mathrm{kg}$ for samples from 4-month-old and 8-month-old animals after 35 days of storage, respectively) (Figure 1).

\subsection{Instrumental color and sensory characteristics}

No significant difference was observed in the $\mathrm{L}^{*}$ values among different MAP and SA treatments $(P>0.05)$ (Table 1). However, ST increased $\mathrm{L}^{*}$ throughout storage time values $(\mathrm{P} \leq 0.05)$ (Table 2 ), corroborating with the results of Martínez-Cerezo et al. (2005).

MAP, SA and ST showed interaction for redness $\left(\mathrm{a}^{*}\right)$, yellowness $\left(b^{\star}\right)$ and chroma $\left(C^{\star}\right)(P \leq 0.05)$. The addition of CO (MAP 2) in the atmosphere increased chroma and redness in lamb loins (Table 1), confirming the beneficial effect of $\mathrm{CO}$ on the stability of red color in meat due to the generation of carboxymyoglobin (Hunt et al., 2004). However, samples under an atmosphere with high $\mathrm{O}_{2}$ level (MAP 3) showed the lowest

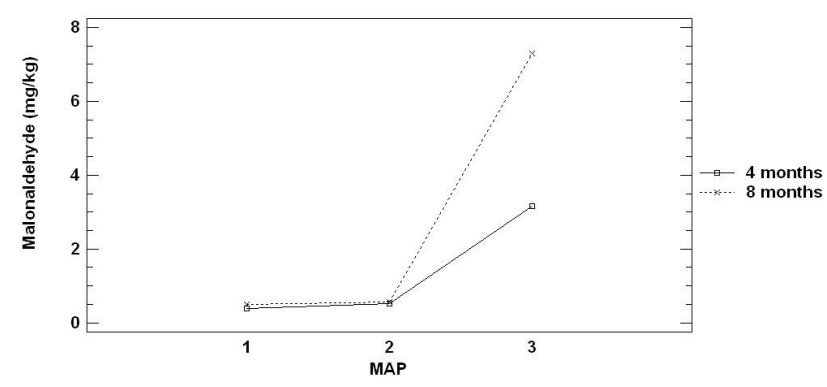

Figure 1. Effect of slaughter age (SA: 4 or 8 months), with three different Modified Atmosphere Packaging (MAP 1: Vacuum; MAP 2: $69.6 \% \mathrm{~N}_{2}+30 \% \mathrm{CO}_{2}+0.4 \%$ CO; MAP 3: $70 \% \mathrm{O}_{2}+30 \% \mathrm{CO}_{2}$ ) on malonaldehyde concentration $(\mathrm{mg} / \mathrm{Kg}$ ) according TBARS (lipid oxidation) test.

redness and chroma values $\left(C^{*}\right)$. Samples packaged in high $\mathrm{O}_{2}$ atmosphere (MAP 3) also exhibited higher hue (h) values when compared to vacuum (MAP 1) and to the CO containing atmosphere (MAP 2) $(\mathrm{P} \leq 0.05)$, which increased during storage time (Table 2), indicating shifts in color between treatments over time toward discoloration (Association of Official Analytical Chemists, 2000).

In agreement with the present study, Linares \& Vergara (2012) also identified the effect of atmosphere on $\mathrm{a}^{\star}, \mathrm{C}^{*}$, and hue in lamb meat, in which an atmosphere with high $\mathrm{O}_{2}$ content showed the highest hue and the lowest $\mathrm{a}^{*}$ and $\mathrm{C}^{\star}$ values and an atmosphere containing a low concentration of $\mathrm{CO}$ had lower hue and higher $\mathrm{a}^{*}$ and $\mathrm{C}^{*}$ values.

At increasing slaughter age and storage time (Table 1 and Table 2), yellowness and hue values of lamb loin also increased, whereas redness and Chroma decreased. This may be related to the increase in lipid oxidation as the slaughter age and storage time increase. Decreased a* values are usually associated to the gradual formation of metmyoglobin and, as a consequence, to meat discoloration (Insausti et al., 2001; Jeremiah, 2001).

\subsection{Microbiological analyses}

MAP and ST showed effect on lactic acid bacteria (LAB) and aerobic psychrotrophic bacteria count $(\mathrm{P} \leq 0.05)$. LAB and aerobic psychrotrophic increased during storage time (Table 2). Samples stored under high $\mathrm{O}_{2}$ (MAP 3) atmosphere showed higher count of aerobic psychrotrophic bacteria $(\mathrm{P} \leq 0.05)$ than those stored in the presence of CO (MAP 2) (Table 3).

Wilkinson et al. (2006) found out the existence of a relationship between bacterial activity and undesirable meat color. Oxygen consumption by psychrotrophic bacteria under atmospheres rich in $\mathrm{O}_{2}$ at meat surface leads to rapid myoglobin oxidation due to decreased partial pressure of $\mathrm{O}_{2}$ within the package. Kennedy et al. (2004) report discoloration at meat surface due to its microbial count. In agreement, in the present study, higher psychrotrophic count provides lower red color intensity in lamb meat. 
Table 3. Effect of slaughter age (SA) and MAP on microbial growth (log CFU/g) of chilled lamb meat stored for 35 days (average \pm Standard error).

\begin{tabular}{|c|c|c|c|c|c|}
\hline \multirow{2}{*}{ Microorganisms } & \multicolumn{2}{|c|}{ Slaughter age } & \multicolumn{3}{|c|}{ Atmosphere $^{1}$} \\
\hline & 4 months & 8 months & MAP 1 & MAP 2 & MAP 3 \\
\hline $\mathrm{PB}^{2}$ & $6.54^{\mathrm{b}} \pm 0.05$ & $6.37^{a} \pm 0.05$ & $6.49^{\mathrm{ab}} \pm 0.06$ & $6.27^{\mathrm{a}} \pm 0.06$ & $6.60^{\mathrm{b}} \pm 0.06$ \\
\hline $\mathrm{LAB}^{3}$ & $5.69^{\mathrm{a}} \pm 0.05$ & $5.82^{\mathrm{a}} \pm 0.05$ & $5.80^{\mathrm{ab}} \pm 0.06$ & $5.84^{\mathrm{b}} \pm 0.06$ & $5.62^{\mathrm{a}} \pm 0.06$ \\
\hline $\mathrm{TC}^{4}$ & $1.53^{\mathrm{a}} \pm 0.07$ & $1.60^{\mathrm{a}} \pm 0.07$ & $1.44^{\mathrm{a}} \pm 0.09$ & $1.64^{\mathrm{a}} \pm 0.09$ & $1.62^{\mathrm{a}} \pm 0.09$ \\
\hline
\end{tabular}

Different lower-case letters at the same row for SA or MAP indicate a significant $(\mathrm{P} \leq 0.05)$ difference; ${ }^{1} \mathrm{MAP} 1=$ vacuum packaging; $\mathrm{MAP} 2=69.6 \% \mathrm{~N}+30 \% \mathrm{CO}+0.4 \% \mathrm{CO}$; MAP $3=70 \% \mathrm{O}_{2}+30 \% \mathrm{CO}_{2} ;{ }^{2} \mathrm{~PB}=$ psychrotrophic bacteria; ${ }^{3} \mathrm{LAB}=$ lactic acid bacteria; ${ }^{4} \mathrm{TC}=$ total coliform.

Table 4. Shelf life (days) of chilled lamb meat samples under different SA x MAP treatments considering the limit value of 7 log CFU/g of aerobic psychrotrophic bacteria and lactic acid bacteria for acceptable quality meat.

\begin{tabular}{ccc}
\hline Treatments $^{1}$ & Psychrotrophic bacteria (days) & Lactic acid bacteria (days) \\
\hline 4 months + MAP 1 & 9.08 & 17.56 \\
4 months + MAP 2 & 9.21 & 12.82 \\
4 months + MAP 3 & 7.61 & 21.53 \\
8 months + MAP 1 & 11.69 & 14.64 \\
8 months + MAP 2 & 13.97 & 16.23 \\
8 months + MAP 3 & 13.14 & 13.14 \\
\hline
\end{tabular}

MAP 1 = vacuum packaging; MAP $2=69.6 \% \mathrm{~N}_{2}+30 \% \mathrm{CO}_{2}+0.4 \% \mathrm{CO} ; \mathrm{MAP} 3=70 \% \mathrm{O}_{2}+30 \% \mathrm{CO}_{2}$.

The first deterioration signs in chilled meat, mainly related to odor (Silva et al., 2010) usually start when the aerobic psychrotrophic bacteria count reaches 7 log CFU/g (Huffman \& Rilley, 2007). According to Leitão (2003) the onset of deterioration may be detected through surface meat discoloration when the psychrotrophic microbial count reaches around $6 \log \mathrm{CFU} / \mathrm{g}$; changes regarding odor and taste may be detected when count reaches 7 and $8 \log \mathrm{CFU} / \mathrm{g}$; respectively; and superficial slime can be observed through a microbial population of $9 \log \mathrm{CFU} / \mathrm{g}$ of meat.

Meat samples from the 4-mounth-old + MAP $3\left(\right.$ high $\left.\mathrm{O}_{2}\right)$ showed the shortest time period to reach count of $7 \log \mathrm{CFU} / \mathrm{g}$ of psychrotrophic bacteria, however, it showed the longest shelf life (21.53-days), when considering the same limit for lactic acid bacteria (Table 4 ).

The high oxygen content in this treatment may have favored the rapid growth of aerobic psychrotrophic bacteria instead of lactic acid bacteria (Bórnez et al., 2009). Kennedy et al. (2004) observed aerobic microbial count of 7 log CFU/g in chilled lamb loin stored under different MAP after 12 days of storage. However, considering the initial microbial load (4.9 log CFU/g), the microbial growth rate in the lamb meat in the present study ( $0.28 \log \mathrm{CFU} /$ day) was lower than that found by these authors (0.41 log CFU/day). In turn, Karabagias et al. (2011) report a count over $7 \log \mathrm{CFU} / \mathrm{g}$ after 11 days of storage for chilled lamb meat packaged in $60 \% \mathrm{CO}_{2}+40 \% \mathrm{~N}_{2}$ and 16 days for lamb meat packaged in $80 \% \mathrm{CO}_{2}+20 \% \mathrm{~N}_{2}$. In both experiments, the initial aerobic load in lamb meat was $4.1 \log \mathrm{CFU} / \mathrm{g}$.

The presence of $\mathrm{CO}$ in MAP 2 inhibited the growth of aerobic psychrotrophic bacteria, however samples packaged in this atmosphere as well as in MAP 1 showed higher LAB count than in MAP $3\left(\right.$ high $\left.\mathrm{O}_{2}\right)$.
SA or MAP did not influence on the count of total coliform or E. coli. During storage, the count of total coliform showed a slight increased at the $14^{\text {th }}$ and the $28^{\text {th }}$ day of storage, which decreased and remained at $1.5 \log \mathrm{CFU} / \mathrm{g}$ until the end of the storage. E. coli count was lower than $1.0 \log \mathrm{CFU} / \mathrm{g}$ in all treatments throughout the storage. The count of the Enterobacteriaceae family in meat must be below $7 \log \mathrm{CFU} / \mathrm{g}$ to prevent its deterioration (Insausti et al., 2001; Jeremiah, 2001). Considering the coliform bacteria as belonging to this family, their count were significantly below the limit in samples of all treatments over 35 days of storage. Karabagias et al. (2011) report a coliform count close to $4 \log \mathrm{CFU} / \mathrm{g}$ at 25 days of storage in lamb meat stored at $80 \%$ $\mathrm{CO}_{2} / 20 \% \mathrm{~N}_{2}$ under refrigeration at $4{ }^{\circ} \mathrm{C}$.

Brazilian legislation establishes the maximum count of $3.69 \log \mathrm{CFU} / \mathrm{g}$ of $E$. coli in aged meat under vacuum (Brasil, 2001). Considering this limit, all lamb samples were in accordance with legislation over the storage period under study.

\section{Conclusions}

High $\mathrm{O}_{2}$ MAP packaging (MAP 3 ) should not be recommended for meat from 8-month-old lamb because it favored lipid oxidation, psychotropic bacteria growth and decreased meat redness over the storage time.

Vacuum (MAP 1) and CO packaging (MAP 2) showed similar effects on most of the meat quality parameters, however, $\mathrm{CO}$ might be better suited for lamb meat storage since it maintained the red color, which is associated to lamb meat freshness.

\section{Acknowledgements}

The authors thank to the Brazilian National Council for Scientific and Technological Development (CNPq), Program MCT/CNPq 014/2010, for the financial support. 


\section{References}

American Meat Science Association - AMSA. (1995). Research guidelines for cookery, sensory evaluation and instrumental textural evaluation of fresh meat (pp. 47). Chicago: AMSA.

American Society for Testing and Material - ASTM. (2001). Standard practice for computing the colors of objects by using the CIE system (pp. 32). Pennsylvania: AOAC.

Association of Official Analytical Chemists - AOAC. (2000). Official methods of analysis of the Association of Official Analytical Chemists (pp. 1). Gaithersburg: AOAC.

Baracat, R. A., Luchiari, A. Fo., Pereira, A. S. C., Silva, S. L., \& Cesar, A. S. M. (2005). Effects of Modified Atmosphere Packaging in preserving portioned bovine meat. In Anais da $42^{\circ}$ Reunião Anual da Sociedade Brasileira de Zootecnia (pp. 42). Goiânia: Sociedade Brasileira de Zootecnia.

Bórnez, R., Linares, M. B., \& Vergara, H. (2009). Systems stunning with $\mathrm{CO}_{2}$ gas on Manchego light lambs: physiologic responses and stunning effectiveness. Meat Science, 82(1), 133-138. http://dx.doi. org/10.1016/j.meatsci.2009.01.003. PMid:20416779.

Bórnez, R., Linares, M. B., \& Vergara, H. (2010). Effect of different gas stunning methods on Manchega suckling lamb meat packed under different modified atmospheres. Meat Science, 84(4), 727-734. http:// dx.doi.org/10.1016/j.meatsci.2009.11.008. PMid:20374849.

Brasil, Ministério da Agricultura Pecuária e Abastecimento - MAPA, Laboratório Nacional de Referência Animal - LANARA. (1981). Métodos analíticos oficiais para controle de produtos de origem animal e seus ingredientes: métodos físicos e químicos. Brasília: LANARA.

Brasil, Ministério da Agricultura, Pecuária e Abastecimento - MAPA, Secretaria de Defesa Agropecuária. (2000, January 24). Aprova o regulamento técnico de métodos de insensibilização para o abate humanitário de animais de açougue (Instrução normativa nº 3, de 17 de janeiro de 2000). Diário Oficial [da] República Federativa do Brasil.

Brasil, Ministério da Saúde. (2001, January 10). Regulamento técnico sobre os padrões microbiológicos para alimentos (Resolução RDC ANVISA/MS no 12, de 2 de janeiro de 2001). Diário Oficial [da] República Federativa do Brasil.

Brasil, Ministério da Agricultura, Pecuária e Abastecimento - MAPA, Secretaria de Defesa Agropecuária. (2003, September 18). Oficializa os métodos analíticos oficiais para análises microbiológicas para controle de produtos de origem animal e água (Instrução Normativa $\mathrm{n}^{\circ}$ 62, de 26 de agosto de 2003). Diário Oficial [da] República Federativa do Brasil.

Camo, J., Beltran, J., \& Roncales, P. (2008). Extension of the display life of lamb with an antioxidant active packaging. Meat Science, 80(4), 1086-1091. http://dx.doi.org/10.1016/j.meatsci.2008.04.031. PMid:22063841.

Church, I. J., \& Parsons, A. L. (1995). Modified Atmosphere Packaging Technology: a review. Journal of the Science of Food and Agriculture, 67(2), 143-152. http://dx.doi.org/10.1002/jsfa.2740670202.

Devine, C. E., Graafhuis, A. E., Muir, P. D., \& Chrystall, B. B. (1993). The effect of growth rate and ultimate $\mathrm{pH}$ on meat quality of lambs. Meat Science, 35(1), 63-77. http://dx.doi.org/10.1016/03091740(93)90070-X. PMid:22060837.

Fernandes, R. P. P., Freire, M. T. A., Paula, E. S. M., Kanashiro, A. L. S., Catunda, F. A. P., Rosa, A. F., Balieiro, J. C. C., \& Trindade, M. A. (2014). Stability of lamb loin stored under refrigeration and packed in different Modified Atmosphere Packaging systems. Meat Science, 96(1), 554-561. http://dx.doi.org/10.1016/j.meatsci.2013.08.005. PMid:24018275.
Fernandes, R. P. P., Venanzi, N. P., Guerra, C. C., Kamimura, E. S., Trindade, M. A., Freire, M. T. A., \& Carrer, C. C. (2010). Chemical composition and microbiological aspects of lamb meat in frozen storage $\left(-18^{\circ} \mathrm{C}\right)$. In Proceedings of the VIII Brazilian Meeting on Chemistry of Food and Beverages (pp. 85). São Carlos: USP.

Guidera, J., Kerry, J. P., Buckley, D. J., Lynch, P. B., \& Morrissey, J. (1997). The effect of dietary vitamin E supplementation on the meat quality of fresh and frozen lamb meat. Meat Science, 45(1), 33-43. http://dx.doi.org/10.1016/S0309-1740(96)00086-1. PMid:22061135.

Huffman, R. D., \& Rilley, J. M. (2007, January). Low-oxygen packaging with CO: a study in food politics that warrants peer review. Food Safety Magazine.

Hunt, M. C., Mancini, R. A., Hachmeister, K. A., Kropf, D. H., Merriman, M., Lduca, G., \& Milliken, G. (2004). Carbon Monoxid in Modified Atmosphere Packaging affects color, shelf life, and microorganisms of beef steaks and ground beef. Journal of Food Science, 69(1), 45-52. http://dx.doi.org/10.1111/j.1365-2621.2004.tb17854.x.

Insausti, K., Beriain, M. J., Purroy, A., Alberti, P., Gorraiz, C., \& Alzueta, M. J. (2001). Shelf life of beef from local Spanish cattle breeds stored under modified atmosphere. Meat Science, 57(3), 273-281. http:// dx.doi.org/10.1016/S0309-1740(00)00102-9. PMid:22061502.

Jakobsen, M., \& Bertelsen, G. (2000). Color stability and lipid oxidation of fresh beef. Development of a response surface model for predicting the effects of temperature, storage time, and modified atmosphere composition. Meat Science, 54(1), 49-57. http://dx.doi.org/10.1016/ S0309-1740(99)00069-8. PMid:22063711.

Jayasingh, P., Cornforth, D. P., Carpenter, C. E., \& Whittier, D. (2001). Evaluation of carbon monoxide (CO) treatment in Modified Atmosphere Packaging or vacuum packaging to increase color stability of fresh beef. Meat Science, 59(3), 317-324. http://dx.doi. org/10.1016/S0309-1740(01)00086-9. PMid:22062786.

Jeremiah, L. E. (2001). Packaging alternatives to deliver fresh meat using short or long-term distribution. Food Research International, 34(9), 749-772. http://dx.doi.org/10.1016/S0963-9969(01)00096-5.

Karabagias, I., Badeka, A., \& Kontominas, M. G. (2011). Shelf life extension of Lamb meat using thyme or oregano essential oils and Modified Atmosphere Packaging. Meat Science, 88(1), 109-116. http://dx.doi.org/10.1016/j.meatsci.2010.12.010. PMid:21211912.

Kennedy, C., Buckley, D. J., \& Kerry, J. P. (2004). Display life of sheep meats retail packaged under atmospheres of various volumes and compositions. Meat Science, 68(4), 649-658. http://dx.doi.org/10.1016/j. meatsci.2004.05.018. PMid:22062542.

Kerth, C. R., Miller, M. F., \& Ramsey, C. B. (1995). Improvement of beef tenderness and quality traits with calcium chloride injection in beef loins 48 hours post mortem. Journal of Animal Science, 73(3), 750-756. PMid:7608007.

Kim, Y. H. B., Frandsen, M., \& Rosenvold, K. (2011). Effect of ageing prior to freezing on colour stability of ovine longissimus muscle. Meat Science, 88(3), 332-337. http://dx.doi.org/10.1016/j. meatsci.2010.12.020. PMid:21354715.

Kim, Y. H. B., Stuart, A., Black, C., \& Rosenvold, K. (2012a). Effect of lamb age and retail packaging types on the quality of long-term chilled lamb loins. Meat Science, 90(4), 962-966. http://dx.doi. org/10.1016/j.meatsci.2011.11.040. PMid:22189085.

Kim, Y. H. B., Bødker, S., Black, C., \& Rosenvold, K. (2012b). Influence of lamb age and high-oxygen Modified Atmosphere Packaging on protein polymerization of long-term aged lamb loins. Food Chemistry, 135(1), 122-126. http://dx.doi.org/10.1016/j.foodchem.2012.04.109.

Lauzurica, S., De La Fuente, J., Díaz, M. T., Álvarez, I., Pérez, C., \& Cañeque, V. (2005). Effect of dietary supplementation of 
vitamin $\mathrm{E}$ on characteristics of lamb meat packed under modified atmosphere. Meat Science, 70(4), 639-646. http://dx.doi.org/10.1016/j. meatsci.2005.02.013. PMid:22063891.

Leitão, M. F. F. (2003). Aspectos microbiológicos das carnes. In: C. Castillo, R. Bromberg, K. M. V. A. B. Cipolli \& L. Miyagusku (Eds.), Higiene e sanitização na indústria de carnes e derivados (pp. 1-5). São Paulo: Varela.

Linares, M. B., \& Vergara, H. (2012). Effect of gas stunning and modified-atmosphere packaging on the quality of meat from Spanish Manchego light Lamb. Small Ruminant Research, 108(1-3), 87-94. http://dx.doi.org/10.1016/j.smallrumres.2012.06.015.

Linares, M. B., Berruga, M. I., Bórnez, R., \& Vergara, H. (2007). Lipid oxidation in lamb meat: Effect of the weight, handling previous slaughter and modified atmospheres. Meat Science, 76(4), 715-720. http://dx.doi.org/10.1016/j.meatsci.2007.02.012. PMid:22061249.

Linares, M. B., Bórnez, R., \& Vergara, H. (2006). Effect of the type of stunning on lipid oxidation and colour of light lamb meat. In Proceedings of the 52th International Congress of Meat Science and Technology (pp. 185-186). Dublin: ICoMST.

Linares, M. B., Bórnez, R., \& Vergara, H. (2008). Effect of stunning systems on meat quality of Manchego suckling lamb packed under modified atmospheres. Meat Science, 78(3), 279-287. http://dx.doi. org/10.1016/j.meatsci.2007.06.009. PMid:22062280.

Lund, M. N., Lametsch, R., Hviid, M. S., Jensen, O. N., \& Skibsted, L. H. (2007). High-oxygen packaging atmosphere influences protein oxidation and tenderness of porcine longissimus dorsi during chill storage. Meat Science, 77(3), 295-303. http://dx.doi.org/10.1016/j. meatsci.2007.03.016. PMid:22061781.

Mancini, R. A., Hunt, M. C., Hachmeister, K. A., Kropf, D. H., \& Johnson, D. E. (2005). Exclusion of oxygen from modified atmosphere packages limits beef rib and lumbar vertebrae marrow discoloration during display and storage. Meat Science, 69(3), 493-500. http://dx.doi. org/10.1016/j.meatsci.2004.09.003. PMid:22062988.

Martínez-Cerezo, S., Sañudo, C., Panea, B., Medel, I., Delfa, R., Sierra, I., Beltrán, J. A., Cepero, R., \& Olleta, J. L. (2005). Breed, slaughter weight and ageing time effects on physico-chemical characteristics of lamb meat. Meat Science, 69(2), 325-333. http://dx.doi.org/10.1016/j. meatsci.2004.08.002. PMid:22062825.

McGeehin, B., Sheridan, J. J., \& Butler, F. (2001). Factors affecting the $\mathrm{pH}$ decline in lamb after slaughter. Meat Science, 58(1), 79-84. http://dx.doi.org/10.1016/S0309-1740(00)00134-0. PMid:22061923.

Parry, R. T. (1993). Principles and applications of Modified Atmosphere Packaging of food. London: Blackie Academic \& Professional. http:// dx.doi.org/10.1007/978-1-4615-2137-2.

Pexara, E. S., Metaxopoulos, J., \& Drosinos, E. H. (2002). Evaluation of shelf life of cured cooked sliced turkey fillets and cooked pork sausages-piroskistored under vacuum and modified atmospheres at 4 and $10^{\circ} \mathrm{C}$. Meat Science, 62(1), 33-43. http://dx.doi.org/10.1016/ S0309-1740(01)00224-8. PMid:22061189.

Prandl, O., Fischer, A., \& Schmidhofer, T. (1994). Tecnologia e higiene de la carne. Zaragoza: Acribia.
Renerre, M. (1990). Factors involved in the discoloration of beef meat. International Journal of Food Science \& Technology, 25(6), 613-630. http://dx.doi.org/10.1111/j.1365-2621.1990.tb01123.x.

Seman, D. L., Drew, K. R., \& Littlejohn, R. P. (1989). Packaging venison for extended chilled storage: comparison of vacuum and Modified Atmosphere Packaging containing 100\% carbon dioxide. Journal of Food Protection, 52(12), 886-893. http://dx.doi.org/10.4315/0362028X-52.12.886.

Seyfert, M., Hunt, M. C., Mancini, R. A., Hachmeister, K. A., Kropf, D. H., Unruh, J. A., \& Loughin, T. M. (2005). Beef quadriceps hot boning and modified-atmosphere packaging influence properties of injection-enhanced beef round muscles. Journal of Animal Science, 83(3), 686-693. http://dx.doi.org/10.2527/2005.833686x. PMid:15705766.

Silva, N., Junqueira, V. C. A., \& Silveira, N. F. A. (2010). Manual de métodos de análise microbiológica de alimentos. São Paulo: Livraria Varela.

Sørheim, O., Westad, F., Larsen, H., \& Alvseike, O. (2009). Colour of ground beef as influenced by raw materials, addition of sodium chloride and low oxygen packaging. Meat Science, 81(3), 467-473. http://dx.doi.org/10.1016/j.meatsci.2008.09.010. PMid:20416604.

Vergara, H., \& Gallego, L. (2001). Effects of gas composition in Modified Atmosphere Packaging on the meat quality of Spanish Manchega lamb. Journal of the Science of Food and Agriculture, 81(14), 13531357. http://dx.doi.org/10.1002/jsfa.953.

Vyncke, W. (1970). Direct determination of the thiobarbituric acid value in trichloroacetic extracts of fish as a measure of oxidative rancidity. Fett Wissenschaft Technologie, 72, 1084-1087.

Watts, B. M. (1962). Meat products. In Proceedings of the Symposium on Food: Lipid and Their Oxidation (pp. 202-219). Westport: AVI Publishing.

Wilkinson, B. H. P., Janz, J. A. M., Morel, P. C. H., Purchas, R. W., \& Hendriks, W. H. (2006). The effect of Modified Atmosphere Packaging with carbon monoxide on the storage quality of master-packaged fresh pork. Meat Science, 73(4), 605-610. http://dx.doi.org/10.1016/j. meatsci.2006.03.001. PMid:22062559.

Xiong, Y. L., Mullins, O. E., Stika, J. F., Chen, J., Blanchard, S. P., \& Moody, W. G. (2007). Tenderness and oxidative stability of postmortem muscles from mature cows of various ages. Meat Science, 77(1), 105-113. http://dx.doi.org/10.1016/j.meatsci.2007.04.012. PMid:22061401.

Zakrys, P. I., Hogan, S. I., O’sullivan, M. G., Allen, P., \& Kerry, J. P. (2008). Effect of oxygen concentration on the sensory evaluation and quality indicators of beef muscle packed under modified atmosphere. Meat Science, 79(4), 648-655. http://dx.doi.org/10.1016/j. meatsci.2007.10.030. PMid:22063026.

Zakrys, P. I., O'sullivan, M. G., Allen, P., \& Kerry, J. P. (2009). Consumer acceptability and physiochemical characteristics of modified atmosphere packed beef steaks. Meat Science, 81(4), 720-725. http:// dx.doi.org/10.1016/j.meatsci.2008.10.024. PMid:20416564. 